\title{
A striking case of deceptive woodpecker colouration: the threatened Helmeted Woodpecker Dryocopus galeatus belongs in the genus Celeus
}

\author{
Martjan Lammertink ${ }^{1,2,3}$ - Cecilia Kopuchian ${ }^{4,5}$ - Hanja B. Brandl ${ }^{6}$. \\ Pablo L. Tubaro ${ }^{5}$ - Hans Winkler ${ }^{6}$
}

\begin{abstract}
The Helmeted Woodpecker Dryocopus galeatus is a threatened species of the Atlantic Forest in southeastern South America. It has traditionally been placed in the genus Dryocopus, but it shows similarities in plumage and structure with woodpeckers in the genus Celeus. We sequenced mitochondrial and nuclear DNA that was sampled from live captured Helmeted Woodpeckers. We found that the Helmeted Woodpecker has a phylogenetic position embedded within the genus Celeus, and recommend its taxonomic treatment as Celeus galeatus. The Helmeted Woodpecker belongs to a clade within Celeus that includes
\end{abstract}

Communicated by J. Fjeldså.

Martjan Lammertink jm1243@cornell.edu

Hans Winkler

hans-christoph.winkler@oeaw.ac.at

1 CICyTTP-CONICET, Materi y España, 3105 Diamante, Entre Ríos, Argentina

2 Proyecto Selva de Pino Paraná, Vélez Sarsfield y San Jurjo s/n, 3352 San Pedro, Misiones, Argentina

3 Cornell Lab of Ornithology, Cornell University, 159 Sapsucker Woods Road, Ithaca, NY 14850, USA

4 CECOAL (Centro de Ecología Aplicada del Litoral)CONICET, Ruta Prov. 5, km 2.5, 3400 Corrientes, Argentina

5 División de Ornitología, Museo Argentino de Ciencias Naturales 'Bernardino Rivadavia', Buenos Aires, Argentina

6 Department of Integrative Biology and Evolution, Konrad Lorenz Institute for Ethology, Veterinary University Vienna, Savoyenstraße 1A, 1160 Vienna, Austria
Kaempfer's Woodpecker C. obrieni, Rufous-headed Woodpecker C. spectabilis, and Cream-coloured Woodpecker $C$. flavus. It has the southernmost distribution range of the woodpeckers in this clade. The Helmeted Woodpecker is sympatric throughout its range with Lineated Woodpecker Dryocopus lineatus and Robust Woodpecker Campephilus robustus and these species from three different genera show a remarkable convergence in plumage colours and patterns. With the inclusion of Helmeted Woodpecker in Celeus, this genus has four out of 15 species on the International Union for Conservation of Nature (IUCN) red list, a higher proportion of red listed species than in the woodpecker family overall.

Keywords Picidae $\cdot$ Molecular phylogeny $\cdot$ Atlantic Forest · Threatened bird · Plumage convergence · Mimicry

\section{Zusammenfassung}

Ein Fall verblüffend irreführender Spechtfärbung: der bedrohte Wellenohrspecht Dryocopus galeatus ist ein Celeus

Der Wellenohrspecht ist eine bedrohte Spechtart der atlantischen Wälder im Südosten Südamerikas. Er wurde traditionellerweise in das Genus Dryocopus eingeordnet, weist aber in Gefieder und Struktur Ähnlichkeiten zur Gattung Celeus auf. Wir sequenzierten mitochondriale und nukleare DNA aus Proben, die lebend gefangenen Individuen entnommen worden waren. Wir fanden heraus, dass der Wellenohrspecht phylogenetisch innerhalb der Gattung Celeus positioniert ist und empfehlen, ihn in dieses Genus zu klassifizieren. Dieser Specht gehört zu einer Stammlinie innerhalb von Celeus, die den Kaempferspecht Celeus obrieni, Zimtkopfspecht C. spectabilis und den Strohspecht 
C. flavus enthält. Er stellt den südlichsten Vertreter dieser Gruppe dar. Sein Verbreitungsgebiet deckt sich mit jenen des Linienspechts Dryocopus lineatus und des Scharlachkopfspechts Campephilus robustus und diese drei Arten aus verschiedenen Genera weisen eine bemerkenswerte Konvergenz in Gefiederfärbung und -muster auf. Zusammen mit dem Wellenohrspecht beinhaltet die 15 Arten zählende Gattung Celeus vier auf der Roten Liste der IUCN stehende Arten, mehr als der Durchschnitt der Familie.

\section{Introduction}

The Helmeted Woodpecker Dryocopus galeatus occurs in the Atlantic Forest in a relatively small range in southern Brazil, eastern Paraguay and northeastern Argentina. It is globally threatened, with International Union for Conservation of Nature (IUCN) vulnerable status, by deforestation and selective logging of its habitat (BirdLife International 2015). In plumage pattern it closely resembles two woodpecker species that are sympatric with it, the Lineated Woodpecker Dryocopus lineatus and the Robust Woodpecker Campephilus robustus (Chebez 1995). The Helmeted Woodpecker was first placed in the genus Dryocopus by Gray (1845). It has also been placed by early authors in the genera Driopicus, Dryopicus, Ceophloeus and Campephilus (Giebel 1877; Bertoni 1901), but it has been maintained in Dryocopus during recent decades (Peters 1948; Short 1982; Sibley and Monroe 1990; Winkler and Christie 2002; Gorman 2014). The Helmeted Woodpecker is a medium sized woodpecker with a body mass of ca. $128 \mathrm{~g}$, and if it were a Dryocopus, it would be the smallest in that genus. The next smallest Dryocopus taxon is the Simeulue White-bellied Woodpecker Dryocopus javensis parvus, with a body mass of ca. $155 \mathrm{~g}$ (Lammertink 2007).

The Helmeted Woodpecker has several morphological characteristics that are reminiscent of woodpeckers in the genus Celeus, including size: body masses range from ca. $65 \mathrm{~g}$ in Waved Woodpecker C. undatus to ca. $153 \mathrm{~g}$ in Chestnut Woodpecker C. elegans hellmayeri (Winkler et al. 1995), a range that overlaps with the body mass of Helmeted Woodpecker. Several plumage patterns (cinnamon wing linings, barred face, long white upper tail coverts, expanded red malar area in male), long and erectable crest feathers, bill shape, and exposed nostrils of Helmeted Woodpecker are found in Celeus but not in Dryocopus (Short 1982). Nevertheless, the black upperparts, extensively red crest, and white-and-black barred underparts of the Helmeted Woodpecker are not found in Celeus, but are very similar to the plumage patterns of several New World
Dryocopus species. Based on the morphological similarities, Short (1982) considered the Helmeted Woodpecker to be an intermediate between the genera Celeus and Dryocopus. Whether or not Celeus and Dryocopus are sister groups remains without consensus in molecular phylogenies. Fuchs et al. (2007) and Fuchs et al. (2013) partly support this relationship; however, other molecular phylogenies indicate with more or less strong node support, and based on three to 12 loci, that Celeus is sister to the Colaptes/Piculus clade (Webb and Moore 2005; Benz et al. 2006; Fuchs et al. 2007; Moore et al. 2011; Fuchs et al. 2013; Winkler et al. 2014). Del Hoyo and Collar (2014) split the Dryocopus species of the New World as Hylatomus, but we follow Winkler et al. (2014) in maintaining these New World species in Dryocopus, along with Old World Dryocopus and with former Mulleripicus species of Asia that are sister to Old World Dryocopus (Fuchs et al. 2007, 2008, 2013; Winkler et al. 2014).

Whereas Short (1982) judged similarities in plumage of woodpecker genera and species to reflect phylogenetic affinity, for instance between the genera Dinopium and Chrysocolaptes, Dryocopus and Campephilus, and Meiglyptes and Hemicircus, or between the species Hairy Woodpecker Leuconotopicus villosus and Downy Woodpecker Dryobates pubescens (sensu Winkler et al. 2014), recent molecular phylogenies indicate that these similar taxa are not sister groups, but are in divergent branches of the woodpecker family (Weibel and Moore 2002a, b; Webb and Moore 2005; Benz et al. 2006; Fuchs et al. 2007, 2013; Winkler et al. 2014). At the same time, highly distinctive woodpecker taxa can form a single clade, as exemplified by the former Mulleripicus and Old World Dryocopus. Thus, to resolve the phylogenetic position of the Helmeted Woodpecker, an approach other than plumage similarity is required.

The recent molecular woodpecker phylogenies cited above have resulted in a generally congruent, well-resolved phylogenetic tree for the woodpecker family. Previous taxonomic riddles in the family such as the position of Nesoctites, Hemicircus, Chrysophlegma, Picus, Micropternus and Sapheopipo have been resolved. The phylogenetic position of the Helmeted Woodpecker, however, remains as one of the most vexing problems in woodpecker taxonomy (Benz and Robbins 2011; Moore et al. 2011). Clarifying the phylogenetic position of the Helmeted Woodpecker is all the more urgent because of its globally threatened status. A resolved phylogeny will aid in making correct inferences about its natural history and ecological requirements from comparisons with the biology of other, genuinely related Woodpecker species.

We present an analysis of the phylogenetic position of the Helmeted Woodpecker based on sequences from mitochondrial genes and a nuclear gene, using DNA 
extracted from live captured individuals. We discuss the relationships of the Helmeted Woodpecker, its plumage convergence with two sympatric woodpecker species, and the implications for comparative research on this threatened woodpecker.

\section{Methods}

\section{Sampled individuals}

The following samples were taken from Helmeted Woodpecker individuals in Misiones Province, Argentina: (1) a blood sample from the brachial vein of an adult male mistnetted at the private reserve Centro de Investigaciones Antonia Ramos (CIAR) near Obera (24.44 S 55.12 W) on 11 October 2012, (2) breast feathers of an adult female mist-netted in Cruce Caballero Provincial Park (26.51 S $53.99 \mathrm{~W}$ ) on 9 September 2013, (3 and 4) belly feathers with feather follicle lining from two sibling nestlings of ca. 16 days old that were being raised by the sampled adult female, on 22 October 2013. Locations 1 and 2-4 were $150 \mathrm{~km}$ apart. All samples were preserved in $96 \%$ ethanol in ultra cold-freezers at $-76^{\circ} \mathrm{C}$. Remaining tissue is stored at Colección Nacional de Tejidos Ultracongelados, Museo Argentino de Ciencias Naturales 'Bernardino Rivadavia', Buenos Aires, Argentina, under the voucher numbers provided in Table 1.

\section{DNA extraction and sequencing}

Two mitochondrial loci, NADH dehydrogenase subunit 2 (ND2) gene and the cytochrome $\mathrm{C}$ oxidase subunit (COI), as well as intron 7 of the nuclear gene $\beta$-fibrinogen $(\beta$ fibrinogen 7) were amplified by PCR and sequenced. The ND2 gene (1041 bp) was amplified with the primers L5216 and H6313 and thermocycle parameters described by Benz and Robbins (2011). A 746 bp fragment of the COI gene was amplified with the primers BIRDF1 and COIBirdR2 and the thermocycle parameters described by Kerr et al. (2009). For $\beta$-fibrinogen 7, a two-step nested PCR was performed to provide a sufficient amount of specific PCR product for further analysis. First, a fragment of approximately 1000 bp in length was amplified using the FIB-17L and FIB-17U primers of Prychitko and Moore (1997) and the nuDNA thermocycle parameters of Benz and Robbins (2011). In the next step, the second internal primers FIBBI7L2 and FIB-BI7U2 were run on a thermocycler to amplify a $877 \mathrm{bp}$ fragment using the following touchdown program: 1 cycle of $95^{\circ} \mathrm{C}$ for $5 \mathrm{~min}$; 6 cycles of $95^{\circ} \mathrm{C}$ for $45 \mathrm{~s}, 58-53{ }^{\circ} \mathrm{C}$, decreasing $1{ }^{\circ} \mathrm{C}$ each cycle, and $72{ }^{\circ} \mathrm{C}$ for $3.5 \mathrm{~min} ; 24$ cycles of $95^{\circ} \mathrm{C}$ for $45 \mathrm{~s}, 50{ }^{\circ} \mathrm{C}$ for $45 \mathrm{~s}$, and 72 ${ }^{\circ} \mathrm{C}$ for $3.5 \mathrm{~min}$; and 1 cycle of $72{ }^{\circ} \mathrm{C}$ for $10 \mathrm{~min}$.
Each PCR was carried out with an Eppendorf Thermocycler in a volume of $25 \mu$ following reactive concentration of Kerr et al. (2009). The second PCR for $\beta$-fibrinogen 7 used the composition as described for the colony PCR in van Dongen et al. (2013), but with 1.25 units of polymerase and $0.1 \mu \mathrm{l}$ of PCR product as template. Length and quality of the amplified $\beta$-fibrinogen 7 products were confirmed by running them on a $1.5 \%$ agarose gel, and the amplified product of the sampled individual with the strongest band was subsequently cloned using a TOPO TA cloning kit (Invitrogen) following the manufacturer's protocol. Sixteen transformed colonies were amplified via colony PCR as described in van Dongen et al. (2013). Successful amplification of the samples was again confirmed on a $1.5 \%$ agarose gel before removing excess primers and dNTPs by digestion with exonuclease I and thermosensitive alkaline phosphatase (Thermo Scientific).

Sequencing reactions for COI and ND2 fragments and the cloned $\beta$-fibrinogen 7 PCR products were performed with the respective PCR primers. For ND2, two internal primers were additionally used for sequencing: H5776 (Klicka et al. 2000) and L5758 (Sorenson et al. 1999). Big Dye chemistry (Applied Biosystems) was used for all the sequencing reactions and the products were sequenced on an ABI PRISM $3130 \times 1$ automated sequencer (Applied Biosystems).

\section{Phylogenetic analysis}

Alignments were produced with MuscLE version 3.8 (Edgar 2004) and optimized manually. The reading frames of all mitochondrial sequences proved to be intact, as expected for functional genes. We obtained sequences from one, two or three fragments per sample. There were no discrepancies between overlapping sections. Both maximum-likelihood and Bayesian methods were used to infer phylogenetic relationships. We conducted a Bayesian analysis on the combined mitochondrial ND2 gene and the nuclear $\beta$-fibrinogen 7 with MrBayes 3.2 (Ronquist et al. 2012). For this analysis, the data set was partitioned by genes, with the $\mathrm{GTR}+\mathrm{I}+\mathrm{G}$ model specified for each partition. All analyses were run for 2,000,000 generations with four Markov chains and uniform priors under default heating values sampling every 100 generations. The first 200,000 generations were discarded as burn-in. Checking with Tracer 1.5 (Rambaut and Drummond 2009) showed that stationarity of likelihoods was achieved before that point. The hierarchical likelihood ratio test implemented in ModelTest 2.1.4 (Posada and Crandall 1998; Darriba et al. 2012) confirmed the GTR $+\mathrm{I}+\mathrm{G}$ model as suitable for the ND2- $\beta$-fibrinogen 7 data set.

Single gene trees were computed with a maximumlikelihood method, which includes an approximate 
Table 1 Specimens of woodpecker species used in this study

\begin{tabular}{|c|c|c|c|c|c|}
\hline \multirow[t]{2}{*}{ Taxon } & \multirow[t]{2}{*}{ Voucher } & \multirow[t]{2}{*}{ Geographic origin } & \multicolumn{3}{|c|}{ Accession number } \\
\hline & & & $\beta$-Fibrinogen & ND2 & COI \\
\hline Dryocopus galeatus & MACN-Or-ct6954 & Misiones, Argentina & & KT216670 & KT216665 \\
\hline D. galeatus & MACN-Or-cp290 & Misiones, Argentina & KT216671 & KT216669 & KT216666 \\
\hline D. galeatus & MACN-Or-cp291 & Misiones, Argentina & & & KT216667 \\
\hline D. galeatus & MACN-Or-cp289 & Misiones, Argentina & & & KT216668 \\
\hline D. pileatus & WSU 8615; KUNHM 6629 & Kentucky, USA; Kansas, USA & U67902 & DQ479187 & NC_008546 \\
\hline D. lineatus & NRM 967106 & Paraguay & DQ352394 & DQ361291 & AY940779 \\
\hline D. martius & MNHN C30 & France & DQ188114 & DQ188166 & GU571371 \\
\hline Mulleripicus funebris & USNM B3804 & Philippines & DQ479215 & DQ479195 & AY940784 \\
\hline Celeus castaneus & UNAM 99-162; USNMC052-10 & Mexico & JF433136 & JF433273 & JQ174335 \\
\hline C. grammicus & LSUMNS 6892; LGEMA-9650 & Loreto, Peru; Brazil & JF433140 & JF433271 & JN801548 \\
\hline C. undatus & KUNHM 5829; USNMF034-11 & Guyana & $\mathrm{JF} 433142$ & JF433266 & JQ174346 \\
\hline C. flavus & KUNHM 5840 & Guyana & JF433145 & JF433279 & AY940775 \\
\hline C. obrieni & Cob1399 & Maranhão, Brazil & KC858931 & KC858944 & \\
\hline C. spectabilis & LSUMNS 10664 & Ucayalí, Peru & JF433138 & JF433280 & \\
\hline C. elegans & KUNHM 5764 & Guyana & JF433129 & JF433261 & JQ174338 \\
\hline C. flavescens & KUNHM 304 & Paraguay & DQ479228 & DQ479174 & \\
\hline C. lugubris & USNM 5899; MACN-Or-ct 1876 & Corrientes, Argentina & JF433133 & JF433255 & FJ027328 \\
\hline C. loricatus & LSUMNS 28510 & Colon, Panama & JF433144 & JF433262 & \\
\hline C. torquatus & LSUMNS 9422; LGEMA-9727 & Pando, Bolivia; Brazil & JF433135 & JF433264 & JN801549 \\
\hline Colaptes auratus & KUNHM 2534 & USA & U67897 & DQ479176 & AY942868 \\
\hline Colaptes melanochloros & NRM 947052; WUD:95-3.2 & Paraguay & DQ352390 & DQ361298 & FR686475 \\
\hline Colaptes punctigula & KUNHM 963; WUD:95-15.1 & Peru & DQ479204 & DQ479178 & FR686479 \\
\hline Colaptes rubiginosus & KUNHM 3926; FMNH:343228 & Guyana & DQ479221 & DQ479182 & FR686489 \\
\hline Piculus chrysochloros & NRM 966938; FMNH 334419 & Paraguay & DQ352392 & DQ361309 & AY927183 \\
\hline Campephilus melanoleucos & NRM 966949 & Paraguay & КС813199 & GU566534 & AY940777 \\
\hline
\end{tabular}

likelihood ratio test with a nonparametric correction described in detail in Anisimova et al. (2011). Program PhyML-aBayes, a version of PhyML (Guindon et al. 2010), was used to compute the trees under a GTR-model, free rates and the BEST search option. In all cases, Campephilus melanoleucos served as outgroup. Similar to the findings of Benz and Robbins (2011), our support values for nodes in the single-gene trees were relatively low.

\section{Results}

A Bayesian analysis of the combined nuclear $\beta$-fibrinogen 7 gene and the mitochondrial ND2 gene yielded a phylogenetic tree with strong node support (Fig. 1) that shows the Helmeted Woodpecker to be embedded within the genus Celeus. According to this tree, the Helmeted Woodpecker is sister to a clade of three Celeus species: Cream-coloured Woodpecker $C$. flavus of the Amazon basin and the northern Atlantic Forest, Rufous-headed
Woodpecker $C$. spectabilis of the western Amazon and Kaempfer's Woodpecker C. obrieni of the Cerrado in northeastern Brazil. The last two are sister species and are rare bamboo-foraging specialists. The only Celeus species that is sympatric with the Helmeted Woodpecker is the Blond-crested Woodpecker C. flavescens, from which it is well separated phylogenetically (Fig. 1) as well as ecologically (as discussed below).

In maximum-likelihood analysis of individual gene trees (Figs. S1-S3), $\beta$-fibrinogen 7 showed generally low resolution near the terminal nodes, but supported the grouping of galeatus with obrieni and spectabilis. In the ND2 tree, galeatus was associated with the obrieni-spectabilis-flavus and castaneus-undatus-grammicus clades, with the lower nodes not resolved. With respect to ND2 genetic distances, its closest relatives are obrieni, spectabilis, and flavus, in that order. The COI tree was the least complete, because sequences are available for only a few Celeus species. Particularly, those species that had been established as close relatives in the foregoing analyses (obrieni and 


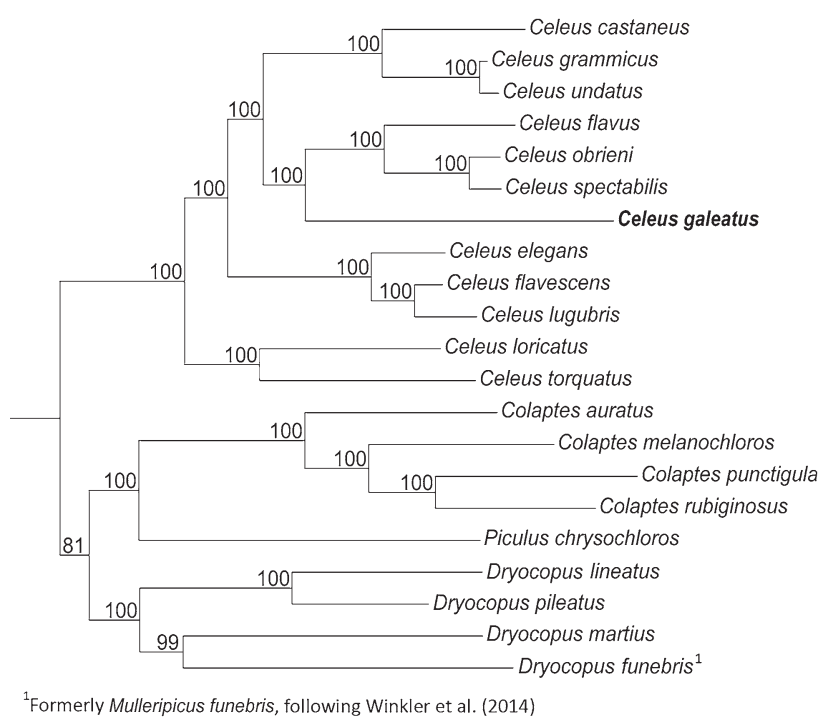

Fig. 1 Bayesian analysis on the combined mitochondrial ND2 gene and the nuclear $\beta$-fibrinogen gene, intron 7. Estimated Bayesian posterior probability is given with each node. Campephilus melanoleucos formed the outgroup

spectabilis) were missing. There was support for the sister group relationship between the representatives of main clades in Celeus, that is, flavus and grammicus; otherwise, the intrageneric relationships were poorly resolved. Importantly, however, in all the individual gene trees, the Helmeted Woodpecker was positioned within the Celeus clade.

\section{Discussion}

A well-supported tree (Fig. 1), constructed with a nuclear intron and a mitochondrial gene, as well as congruent individual gene trees show that the Helmeted Woodpecker is embedded within the genus Celeus, and we thus recommend its taxonomic treatment as Celeus galeatus. Our finding based on molecular sequences that the Helmeted Woodpecker belongs in the genus Celeus is congruent with the similarities in plumage and exposed nostrils between this species and Celeus woodpeckers, as first pointed out by Short (1982). Another similarity is that in Celeus and Helmeted Woodpecker, there is little to no differentiation between sexes at the nestling stage (Winkler et al. 1995; Lammertink and Klavins 2012; M. Lammertink unpublished data), whereas in Dryocopus, including the former Mulleripicus, nestlings can readily be sexed (Winkler et al. 1995). Several behaviours of Helmeted Woodpeckers are unlike those in any Dryocopus, including being active at crepuscular hours and roosting in natural decay cavities (Cockle 2010; Lammertink et al. 2012). There is no information available yet to assess whether such behaviours are found in other Celeus woodpeckers. Mention has been made of the voice of Helmeted Woodpeckers being reminiscent of Celeus (Collar et al. 1992; Brooks et al. 1993), though both the Blond-crested Woodpecker Celeus flavescens and the Lineated Woodpecker Dryocopus lineatus have calls in their vocal repertoires that are rather similar to the long call of the Helmeted Woodpecker (M. Lammertink pers. obs.). The tududu contact call of Helmeted Woodpecker does not appear to have an equivalent in any Celeus or Dryocopus species.

Helmeted Woodpecker forms a clade with Creamcoloured Woodpecker C. flavus, Rufous-headed Woodpecker $C$. spectabilis and Kaempfer's woodpecker $C$. obrieni (Fig. 1), three taxa that occur over a wide range of continental South America, from the Amazon basin to the Cerrado and northern Atlantic Forest in northeast Brazil. The Helmeted Woodpecker is the sister taxon of the other three species in this clade and occurs south of the ranges of the other three. Two of the species in the clade, Rufousheaded Woodpecker C. spectabilis and Kaempfer's woodpecker $C$. obrieni are bamboo specialists that do nearly all (obrieni) or a substantial part (spectabilis) of their foraging on ants that live inside stems of bamboo of the genus Guadua (Kratter 1998; Leite et al. 2013; de Sousa Azevedo et al. 2013). The Helmeted Woodpecker mostly forages on wood substrates but has also been recorded to forage on ants in Guadua trinii and Merostachys multiramea bamboo (Santos 2008; Lammertink et al. 2012). The Creamcoloured Woodpecker C. flavus however primarily forages on nests of arboreal ants (Winkler et al. 1995).

The only Celeus that occurs sympatrically with the Helmeted Woodpecker is the Blond-crested Woodpecker, which is part of another clade in Celeus of species of open woodlands, secondary forests, plantations and parks, including the Chestnut woodpecker Celeus elegans and the Pale-crested Woodpecker Celeus lugubris (Fig. 1). The Ochre-backed Woodpecker Celeus ochraceus of open Cerrado woodlands is also part of this clade (Benz and Robbins 2011). In Misiones province, Argentina, at sites where the Helmeted Woodpecker reaches its highest densities in tall, well preserved forests, the Blond-crested Woodpecker is rare, and vice versa, at sites where the Blond-crested Woodpecker is common, in opened-up forests, the Helmeted Woodpecker is rare or absent (Bodrati and Cockle 2006). If the Helmeted Woodpecker were a Dryocopus, it would be the only Dryocopus to occur sympatrically throughout its range with another Dryocopus woodpecker, that is, the Lineated Woodpecker. It is, on the other hand, not uncommon for two or more Celeus to occur sympatrically, with up to four and five Celeus species having been recorded at sites in the Amazon basin (Terborgh et al. 1984; Zimmer et al. 1997; Zimmer and Hilty 1997; HW pers. obs.). 
Helmeted Woodpecker is one of three woodpecker species in the Atlantic Forest of similar appearance; that is, woodpeckers with black upperparts, black tails, black-andwhite barred underparts, and prominent red crests in both sexes (Fig. 2). They are the three largest woodpecker species in the woodpecker assemblage of eight species in tall Atlantic Forest, although the other two are substantially heavier than the Helmeted Woodpecker, with the Lineated Woodpecker weighing ca. $210 \mathrm{~g}$ and the Robust Woodpecker ca. $270 \mathrm{~g}$. The three species belong to divergent clades in the woodpecker family (Benz et al. 2006; Fuchs et al. 2007). Plumage convergence in sympatric species of divergent lineages is a frequent phenomenon in woodpeckers, with striking examples including the convergence between sympatric Dinopium and Chrysocolaptes, between Dryocopus and Campephilus, and Dendrocopos and Leiopicus (Cody 1969; Winkler et al. 1994; Prum 2014; Leiopicus sensu Winkler et al. 2014). There have been several explanations proposed for plumage convergence in woodpeckers from divergent lineages (Winkler et al. 1994), including interspecific territoriality (Cody 1969; 1973), which is not supported by field observations. Prum and Samuelson (2012) proposed that the mechanism for plumage convergence is interspecific social dominance mimicry (see also Diamond 1994; Rainey and Grether 2007), in which a subordinate species evolves to mimic and deceive a dominant species into misidentifying the mimic as an individual of the dominant species, and into overestimating its size and the costs of aggression. The body mass ratios of $78 \%$ between Lineated and Robust Woodpecker, and $61 \%$ between Helmeted and Lineated Woodpecker, are above the average ratio of 56-58\% between presumed mimics and models in birds, although the ratio ranges from
18 to $90 \%$ (Prum 2014). Nearly all examples of plumage convergence in woodpeckers of divergent lineages involve species pairs, and the Robust-Lineated-Helmeted Woodpecker complex is the clearest example of a convergent trio of species in woodpeckers. In other bird families, complexes of multiple species of presumed mimics occur, with a complex of six similar species of six different genera of tyrant flycatchers (Tyrannidae) as an outstanding example (Prum 2014).

With the inclusion of the Helmeted Woodpecker in Celeus, four out of 15 Celeus species are on the IUCN red list of globally threatened birds (BirdLife International 2015). Helmeted Woodpecker (vulnerable), Kaempfer's Woodpecker (endangered), and Atlantic Black-breasted Woodpecker $C$. tinnunculus (vulnerable) are threatened by clearance and modification of specialised habitats: tall mature Atlantic Forest in the cases of Helmeted Woodpecker and Atlantic Black-breasted Woodpecker, and breaks of Guadua paniculata bamboo in Cerrado woodlands in the case of the Kaempfer's Woodpecker. In addition, the Ringed Woodpecker $C$. torquatus has nearthreatened status. It occurs in a wider range of primary and disturbed habitats than the other three, but is under pressure from deforestation in the northern Amazon basin. Across the woodpecker family, 42 out of 254 species $(17 \%)$ are Red Listed, so the proportion of Red Listed species in Celeus (27 \%) is relatively high. The IUCN (2015) Red List is based on a taxonomic reassessment of the non-passeriformes by del Hoyo and Collar (2014), which led to many taxonomic changes across the Picidae based on consistent criteria for voice and plumage characters. Consequently, the high proportion of Red Listed species in Celeus cannot be attributed to a different taxonomic treatment of Celeus
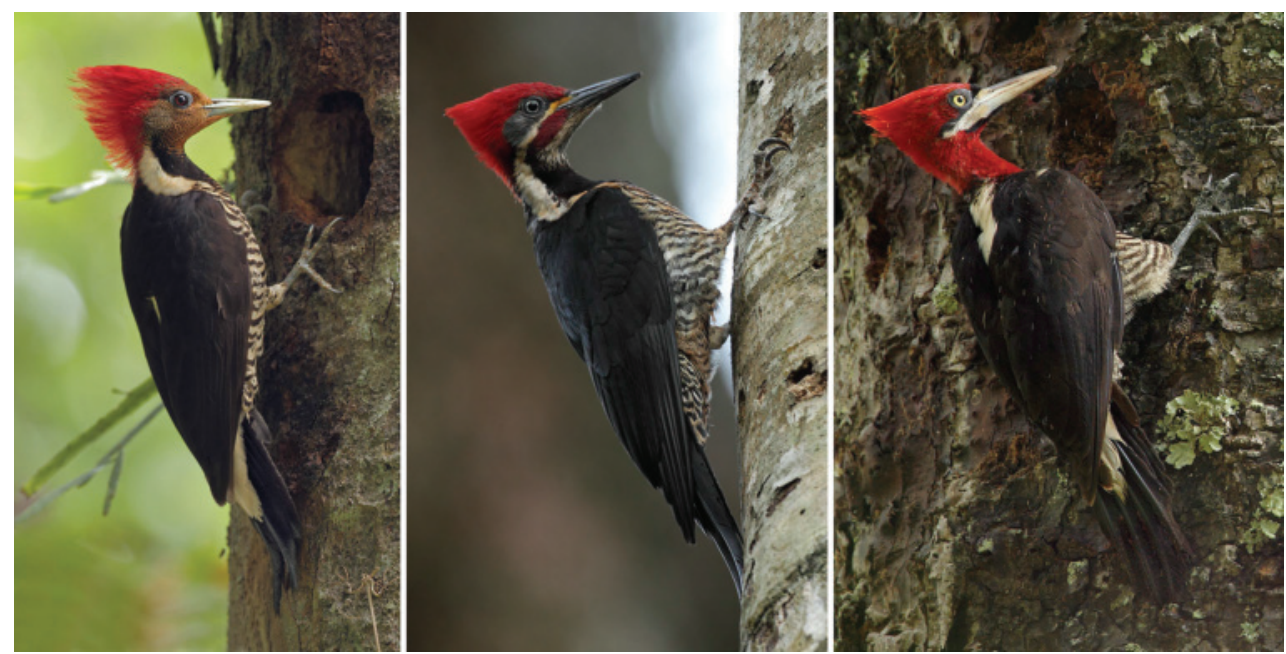

Fig. 2 The Atlantic Forest woodpecker species involved in possible tri-fold interspecific social dominance mimicry. From left to right: Helmeted Woodpecker Celeus galeatus, Lineated Woodpecker
Dryocopus lineatus, Robust woodpecker Campephilus robustus. Photos by M. Lammertink taken in Parque Provincial Cruce Caballero, Misiones, Argentina 
versus other Picids. Our finding that the Helmeted Woodpecker belongs in the genus Celeus allows for comparative research and the development of common conservation strategies for the threatened congeners.

Acknowledgments We thank Ministerio de Ecología of Misiones province, Arauco Argentina (formerly Alto Paraná S. A.) and Fundación Bosques Nativos Argentinos for research and collection permits. Cecilia Kopuchian and Pablo Tubaro thank Centro de Investigaciones Antonia Ramos (CIAR) in Oberá, Misiones, for access. The Cornell Lab of Ornithology, National Geographic, and W.C. Hunter supported fieldwork. Grants from CONICET, ANPCyT and IDRC Canada supported laboratory work. Carlos Ferreyra, Juan Klavins, and Natalia García assisted in captures of Helmeted Woodpeckers. Hans Winkler especially acknowledges the generous support provided by the Department of Integrative Biology and Evolution.

\section{References}

Anisimova M, Gil M, Dufayard JFO, Dessimoz C, Gascuel O (2011) Survey of branch support methods demonstrates accuracy, power, and robustness of fast likelihood-based approximation schemes. Syst Biol 60:685-699

Benz BW, Robbins MB (2011) Molecular phylogenetics, vocalizations, and species limits in Celeus woodpeckers (Aves: Picidae). Mol Phylogenet Evol 61:29-44

Benz BW, Robbins MB, Peterson AT (2006) Evolutionary history of woodpeckers and allies (Aves: Picidae): placing key taxa on the phylogenetic tree. Mol Phylogenet Evol 40(2):389-399

Bertoni A de W (1901) Aves nuevas del Paraguay. Talleres Nacionales, Asunción

BirdLife International (2015) IUCN red list for birds. http://www. birdlife.org. Accessed 6 Jan 2015

Bodrati A, Cockle K (2006) Habitat, distribution, and conservation of Atlantic Forest birds in Argentina: notes on nine rare or threatened species. Ornitol Neotrop 17:243-258

Brooks TM, Barnes R, Bartrina L, Butchart SHM, Clay RP, Esquivel EZ, Etcheverry NI, Lowen JC, Vincent J (1993) Bird surveys and conservation in the Paraguayan Atlantic Forest: Project CANOPY'92 final report. Study Report Number 57. BirdLife International, Cambridge, UK

Chebez JC (1995) Nuevos datos sobre Dryocopus galeatus (Piciformes: Picidae) en Argentina. Hornero 14:55-57

Cockle KL (2010) Interspecific cavity-sharing between a Helmeted Woodpecker (Dryocopus galeatus) and two White-eyed Parakeets (Aratinga leucophthalma). Wilson J Ornithol 122:803-806

Cody ML (1969) Convergent characteristics in sympatric species: a possible relation to interspecific competition and aggression. Condor 71:222-239

Cody ML (1973) Character convergence. Annu Rev Ecol Syst 4:189-211

Collar NJ, Gonzaga LP, Krabbe N, Madroño Nieto A, Naranjo LG, Parker TA, Wege DC (1992) Threatened birds of the Americas: the ICBP/IUCN Red Data Book. International Council for Bird Preservation, Cambridge

Darriba D, Taboada GL, Doallo R, Posada D (2012) jModelTest 2: more models, new heuristics and parallel computing. Nat Meth 9:772

de Sousa Azevedo L, Aleixo A, Santos MP, Sampaio I, Schneider H, Vallinoto M, do Rêgo PS (2013) New molecular evidence supports the species status of Kaempfer's woodpecker (Aves, Picidae). Genet Mol Biol 36:192-200

del Hoyo J, Collar NJ (2014) Illustrated checklist of the birds of the world: Non-passerines, vol 1. Lynx Edicions, Barcelona

Diamond JM (1994) Two-faced mimicry. Nature 367:683-684

Edgar RC (2004) MUSCLE: a multiple sequence alignment method with reduced time and space complexity. BMC Bioinformatics 5:113

Fuchs J, Ohlson JI, Ericson PGP, Pasquet E (2007) Synchronous intercontinental splits between assemblages of woodpeckers suggested by molecular data. Zool Scripta 36:11-25

Fuchs J, Pons J-M, Ericson PGP, Bonillo C, Couloux A, Pasquet E (2008) Molecular support for a rapid cladogenesis of the woodpecker clade Malarpicini, with further insights into the genus Picus (Piciformes: Picinae). Mol Phylogenetics Evol 48:34-46

Fuchs J, Pons J-M, Liu L, Ericson PGP, Couloux A, Pasquet E (2013) A multi-locus phylogeny suggests an ancient hybridization event between Campephilus and melanerpine woodpeckers (Aves: Picidae). Mol Phylogenetics Evol 67:578-588

Giebel CGA (1877) Thesaurus ornithologiae: Repertorium der gesammten ornithologischen Literatur und Nomenclator sämmtlicher Gattungen und Arten der Vögel, nebst Synonymen und geographischer Verbreitung, vol 3. Brockhaus, Leipzig [1872-1877]

Gorman G (2014) Woodpeckers of the world. The complete guide. Helm, London

Gray GR (1845) The genera of birds: comprising their generic characters, a notice of the habits of each genus, and an extensive list of species referred to their several genera, vol 2. Longman, Brown, Green and Longmans, London, pp 1844-1849

Guindon S, Dufayard JF, Lefort V, Anisimova M, Hordijk W, Gascuel O (2010) New algorithms and methods to estimate maximum-likelihood phylogenies: assessing the performance of PhyML 3.0. Syst Biol 59:307-321

Kerr KCR, Lijtmaer DA, Barreira AS, Hebert PDN, Tubaro PL (2009) Probing evolutionary patterns in neotropical birds through DNA barcodes. PLoS One 4:e4379. doi:10.1371/ journal.pone.0004379

Klicka J, Johnson KP, Lanyon SM (2000) New world nine-primaried oscine relationships: constructing a mitochondrial DNA framework. Auk 117:321-336

Kratter AW (1998) The nests of two bamboo specialists: Celeus spectabilis and Cercomacra manu. J Field Ornithol 69:37-44

Lammertink M (2007) Community ecology and logging responses of Southeast Asian woodpeckers (Picidae, Aves). Dissertation, Universiteit van Amsterdam

Lammertink M, Klavins J (2012) Nest and fledgling of Helmeted Woodpecker (Dryocopus galeatus). Ornitol Neotrop 23:455-460

Lammertink M, Cockle KL, Bodrati A, Santos REF (2012) Helmeted Woodpecker (Dryocopus galeatus). In: Schulenberg TS (ed) Neotropical birds online. Cornell Lab of Ornithology, Ithaca

Leite GA, Pinheiro RT, Marcelino DG, Figueira JEC, Delabie JHC (2013) Foraging behavior of Kaempfer's woodpecker (Celeus obrieni), a bamboo specialist. Condor 115:221-229

Moore WS, Overton LC, Miglia KJ (2011) Mitochondrial DNA based phylogeny of the woodpecker genera Colaptes and Piculus, and implications for the history of woodpecker diversification in South America. Mol Phylogenet Evol 58:76-84

Peters JL (1948) Check-list of birds of the world, vol 6. Museum of Comparative Zoology, Cambridge

Posada D, Crandall KA (1998) Modeltest: testing the model of DNA substitution. Bioinformatics 14:817-818

Prum RO (2014) Interspecific social dominance mimicry in birds. Zool J Linn Soci 172:910-941 
Prum RO, Samuelson L (2012) Evolution of interspecific social dominance mimicry modeled by the 'Hairy-Downy' game. J Theor Biol 313:42-60

Prychitko TM, Moore WS (1997) The utility of DNA sequences of an intron from the $\beta$-fibrinogen gene in phylogenetic analysis of woodpeckers (Aves: Picidae). Mol Phylogenetics Evol 8:193-204

Rainey MM, Grether GF (2007) Competitive mimicry: synthesis of a neglected class of mimetic relationships. Ecology 88:2440-2448

Rambaut A, Drummond AJ (2009) Tracer v1.5.0.—Available from http://beast.bio.ed.ac.uk/Tracer

Ronquist F, Teslenko M, van der Mark P, Ayres DL, Darling A, Höhna S, Larget B, Liu L, Suchard MA, Huelsenbeck JP (2012) MrBayes 3.2: efficient Bayesian phylogenetic inference and model choice across a large model space. Syst Biol 61:539-542

Santos REF (2008) Dryocopus galeatus (Temminck, 1822): registro documentado e novas informações para o Vale do Rio Itajaí, Santa Catarina, Brasil. Atualidades Ornitológicas 143:20-23

Short LL (1982) Woodpeckers of the world. Delaware Museum of Natural History, Greenville

Sibley CG, Monroe BL (1990) Distribution and taxonomy of birds of the world. Yale University Press, New Haven

Sorenson MD, Ast JC, Dimcheff DE, Yuri T, Mindell DP (1999) Primers for a PCR-based approach to mitochondrial genome sequencing in birds and other vertebrates. Mol Phylogenetics Evol 12:105-114

Terborgh J, Fitzpatrick JW, Emmons L (1984) Annotated checklist of bird and mammal species of Cocha Cashu Biological Station, Manu National Park, Peru. Field Museum of Natural History, Chicago

van Dongen WFD, White J, Brandl HB, Moodley Y, Merkling T, Leclaire S, Pierrick B, Danchin E, Hatch SA, Wagner RH (2013)
Age-related differences in the cloacal microbiota of a wild bird species. BMC Ecol 13:11

Webb DM, Moore WS (2005) A phylogenetic analysis of woodpeckers and their allies using $12 \mathrm{~S}$, Cyt $\mathrm{b}$, and COI nucleotide sequences (class Aves; order Piciformes). Mol Phylogenetics Evol 36:233-248

Weibel AC, Moore WS (2002a) Molecular phylogeny of a cosmopolitan group of woodpeckers (genus Picoides) based on COI and $c y t b$ mitocondrial gene sequences. Mol Phylogenetics Evol 22:65-75

Weibel AC, Moore WS (2002b) A test of a mitocondrial gene-based phylogeny of woodpeckers (genus Picoides) using an independent nuclear gene, $\beta$-fibrinogen Intron 7. Mol Phylogenetics Evol 22:247-257

Winkler H, Christie DA (2002) Family Picidae (woodpeckers). In: del Hoyo J, Elliott A, Sargatal J (eds) Handbook of the birds of the world, vol 7. Lynx, Barcelona, pp 296-555

Winkler H, Christie DA, Nurney D (1994) The colourful world of woodpeckers: an oriental perspective. OBC Bull 19:30-33

Winkler H, Christie DA, Nurney D (1995) Woodpeckers-a guide to the woodpeckers, piculets and wrynecks of the world. Pica Press, Sussex

Winkler H, Gamauf A, Nittinger F, Haring E (2014) Relationships of Old World woodpeckers (Aves: Picidae) - new insights and taxonomic implications. Ann Nat Hist Mus Wien B 116:69-86

Zimmer KJ, Hilty SL (1997) Avifauna of a locality in the upper Orinoco drainage of Amazonas, Venezuela. Ornithol Monogr 48:865-885

Zimmer KJ, Parker TA III, Isler ML, Isler PR (1997) Survey of a Southern Amazonian avifauna: the Alta Floresta region, Mato Grosso, Brazil. Ornithol Monogr 48:887-918 